\title{
Obituary
}

\section{DR. N. L. BRITTON}

$\mathrm{T}$ HE death on June 19 of Dr. Nathaniel Lord Britton, for many years director-in-chief of the New York Botanical Garden, removes one of the most prominent figures in North American botany. Born on January 15, 1859, Britton took the degree of E.M. at Columbia University in 1879, proceeding to $\mathrm{Ph} . \mathrm{D}$. in 1881 . It will come as a surprise to many who knew his work that the first nine years of his professional career (1879-87) were spent as assistant in geology at Columbia University, and that fourteen of his early papers published during the period 1882-89 dealt with geological subjects. His heart even then, however, was in botany, as is shown by the list of twentynine botanical papers covering the period 187887. From 1880 until 1890, Britton was botanist and assistant geologist to the New Jersey Geological Survey. His appointment as instructor in botany at Columbia University in 1887, followed by promotion to adjunct professor in 1890 and professor (1891-96), coincided with a great increase in his botanical output.

Among Britton's more important publications during the period 1888-96 was a series of papers on "New or noteworthy North American Phanerogams" and "An Enumeration of the Plants collected by Dr. H. H. Rusby in South America". About the year 1888, Britton became interested in botanical nomenclature, which was then becoming a subject of keen controversy. He was always a rigid adherent of the principle of 'priority of publication' and rejected the arguments based on 'convenience' which eventually led to the acceptance, by successive International Botanical Congresses, of the principle of conservation of wellknown generic names. His nomenclatural views led to the publication of numerous name-changes such as those in the "Preliminary Catalogue of Anthophyta and Pteridophyta reported as growing spontaneously within 100 miles of New York City" (1888). These divergences in nomenclatural views between two different groups of botanists in the United States culminated in the rejection, by one of these groups, of the International Rules of Nomenclature (1905) and the formulation of a rival set of rules entitled "American Code of Botanical Nomenclature" (Bull. Torr. Bot. Club, $34,167 ; 1907)$. It is now hoped that the changes introduced by means of friendly agreement into the third edition of the International Rules (now in the press) will make them acceptable to the vast majority of botanists. It is pleasant to record that though Britton seems to have retained his nomenclatural views unaltered until the end, he never allowed them to interfere with the cordial relations subsisting between the New York Botanical Garden and other institutions.

The third period of Britton's career was as director-in-chief of the New York Botanical Garden (1896-1929). Among the more important floras prepared by him are the "Illustrated Flora of the Northern United States, etc." (1896-98; second edition, 1913), "Manual of the Flora of the Northern States and Canada" (1901 ; third edition, 1907), "American Trees" (1908), "Flora of Bermuda" (1918), "Bahama Flora" (1920, with C. F. Millspaugh), and "Botany of Porto Rico and the Virgin Islands" (1923-, with P. Wilson). The lavishly illustrated monograph, "The Cactaceæ" (4 volumes, 1919-23), written in collaboration with the late Dr. J. N. Rose, was one of his most important pieces of taxonomic research. In connexion with the preparation of these works, Britton travelled extensively in the West Indies and elsewhere.

Britton also acted as editor of the Bulletin of the Torrey Botanical Club (1888-97) and as joint editor of the "North American Flora" (1905-). The new periodical Brittonia (1931-), issued by the New York Botanical Garden, was named in Britton's honour after his retirement from official duties.

On his retirement from Columbia University he was made emeritus professor and, among his many honours, he was elected a foreign member of the Linnean Society of London in $\mathbf{1 9 2 5 .}$

Dr. Britton lost his wife, Mrs. Elizabeth Gertrude Britton, on February 25 of this year, and her death must have been a great shock to him as they were very devoted to each other. Like her husband, she was a keen botanist and made a special study of the mosses her life work. She was one of the prime movers in organising the Wild Flower Preservation Society of America, and was also one of the principal members of the Torrey Botanical Club which promoted the establishment of the New York Botanical Garden, of which, after its incorporation in 1891, Dr. Britton became director-in-chief in 1896. Her valuable volunteer services in the care of the Moss Collection was recognised in 1912 by her official appointment as honorary curator of the mosses in the herbarium of the New York Botanical Garden.

\section{T. A. Spragut.}

WE regret to announce the following deaths:

Father Giuseppe Gianfranceschi, president of the Pontifical Academy of Sciences and director of the Vatican Broadcasting Station, on July 9, aged fifty-nine years.

Mr. H. O. Larsen, one of the founders of the Experimental and Research Station, Cheshunt, Herts, and a leading horticulturist, on July 3, aged sixty-four years.

Dr. Marion Newbigin, editor of the Scottish Geographical Magazine and author of numerous geographical works, on July 20.

Dr. Jakob J. Sederholm, director of the Geological Survey of Finland, on June 27, aged seventy-one years. 